レーザーオリジナル

\title{
LD励起固体レーザー用 $\mathrm{Nd} ： \mathrm{YVO}_{4}$ 結晶 桑野泰彦*・斎藤誠
}

(1990年 7 月17日 受理)

\section{Nd : $\mathrm{YVO}_{4}$ Single Crystal for LD Pumped Solid State Laser}

Yasuhiko KUWANO* and Seiichi SAITO*

(Recieved July 17, 1990)

\begin{abstract}
Neodymium doped yittrium vanadate $\left(\mathrm{Nd}: \mathrm{YVO}_{4}\right)$ single crystals were successfully grown from the stoichiometric melt by Chochralski's method. The effective distribution coefficient of $\mathrm{Nd}$ for $\mathrm{Nd}: \mathrm{YVO}_{4}$ growth was 0.57 . As-grown crystals of undoped $\mathrm{YVO}_{4}$ showed a slightly large and wide optical absorption at the short wavelength region near the absorption edge. However it was improved by an annealing at $1200^{\circ} \mathrm{C}$ for $10 \mathrm{~h}$ in an oxygen atmosphere. The absorption by $\mathrm{Nd}^{3+}$ in $\mathrm{Nd}$ : $\mathrm{YVO}_{4}$ was very strong compared with that in $\mathrm{Nd}$ : $\mathrm{YAG}$ of the same $\mathrm{Nd}$ concentration. The refractive indices of $\mathrm{YVO}_{4}$ were also measured by a minimum deviation method. The principal refractive index at $\lambda=1064 \mathrm{~nm}$ (the main oscillating wavelength of a $\mathrm{Nd}$ : $\mathrm{YVO}_{4}$ laser) was $1.9573(\omega)$ and $2.1652(\varepsilon)$.
\end{abstract}

Key Words: $\mathrm{YVO}_{4}, \mathrm{Nd}: \mathrm{YVO}_{4}, \mathrm{LD}$ pumped laser, Crystal growth, Optical absorption, Refrac tive index.

\section{1.はじめに}

$\mathrm{Nd}: \mathrm{YVO}_{4}$ (ネオジム添加バナジン酸イット リウム, Nd doped Yttrium Vanadate) 結晶は, 半導体レーザーダイオード（LD）励起固体レー ザー材料として優れた性質を有する。例えば $\mathrm{Nd}$ : Y AGと較べ, レーザー発振しきい值が低 く, 発振高率が高い。さらに発振出力の励起波 長依存性が少ないため, LDの温度管理が緩や かでよい等実用上好ましい特性が確認されてい る1)。Ndを約 1 at\%添加したNd: $\mathrm{YVO}_{4}$ の誘導 放出断面積は約 $3 \times 10^{-18} \mathrm{~cm}^{2}$ でNd: YAGの数倍

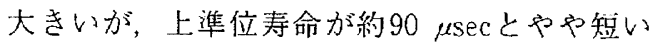
ので ${ }^{1,2)}$, CW 発振用として適した材料と言え
る。また, $\mathrm{YVO}_{4}$ は一軸性結晶であるため直線 偏光レーザーが得られる事も特徵となってい る。

ところで, $\mathrm{Nd}: \mathrm{YVO}_{4}$ はCLEO (Conference on Laser and Electro Optics) '87およびCLEO '88で LD励起高効率発振（スロープ効率約50 $60 \%)^{3,4)}$ が報告されて以来にわかに注目され始 めたが，結晶育成に高度な技術を要するため一 般に入手することが困難な状沉にあった。結晶 育成の研究の歴必は意外に古く，1960年代の末 期から，1970年代初期にかけて，ベルヌーイ 法 $^{5)}$, フローティングゾーン法 ${ }^{6)}$, フラックス 法 $^{7)}$,引き上げ法 ${ }^{8,9)}$ など種々の方法が試みら れ，その後も研究は続けられてきたが，原料の

*日本電気 (株) 材料開発試作センター（テ213川崎市宮前区宮崎4-1-1）

* NEC Corporation, Material Development Center (4-1-1 Miyazaki, Miyamae-ku, Kawasaki, Kanagawa 213) 
五酸化バナジウムが分解蒸発し易いため結晶組 成が一定せず，良質結晶を得ることが困難で， 実用化されなかった。また、レーザー発振岀験 に拈いてもカラーセンターや熱的な問題でラン プ励起ではNd：YAGを倰ぐことが出来なかっ た に緩和されることになったが，光学的均一性の 優れた結晶を再現性よく得る技術は進展してい なかった。

本報告では $\mathrm{YVO}_{4}$ 育成のため，この度特に開 発した結晶引き上げ技術を用いて行なった結晶 育成の概要および得られた結晶の性質, 特に光 吸収特性と屈折率の測定結果について述べる。 なお， $\mathrm{Nd}: \mathrm{YVO}_{4}$ の分光（偏光）およびレーザー 発振特性については本訫別稿 ${ }^{1)}$ に委栘る。

\section{2. 実験方法}

2.1 結晶育成および熱処理 結晶龍成は一般的な高周波誘導加熱方式の常 压引き上げ装置を用いて行なった。原料は純度 $99.999 \% の \mathrm{Y}_{2} \mathrm{O}_{3}$ (酸化イットリウム), 純度 $99.99 \% の \mathrm{~V}_{2} \mathrm{O}_{5}$ (五酸化バナジウム) さらに, $\mathrm{Nd}$ 添加する場合は純度 $99.999 \% の \mathrm{Nd}_{2} \mathrm{O}_{3}$ （酸 化ネオジム）の各粉末を使用し，るつぼは直 径 $50 \mathrm{~mm}$, 深さ $50 \mathrm{~mm}$, 板厚 $1.5 \mathrm{~mm}$ のイリジウ ム製のものを用い, ジルコニア耐火物で保温し た。単結晶育成は原料科量, 混合, 焼成, 坩堝 への充填, 引き上げ育成, 徐冷の順序で行った。 結晶引き上げ育成には方位の定まった種子結晶 が必要なので,この度は,この種子結晶作りか ら始めた。そのため, 最初の育成は種子結晶の 代わりにイリジウム棒を用い，金属棒の先端に 固化した多結晶のブロックから単結晶部分を切 りだし，それを種子としてある程度の大きさの 結晶を作成し，その単結晶から必要方位の種結 晶を切り出すという方法を採った。結晶育成条 件は良質結晶を得るための多くの予㑋実験の結 果から決定されたもので, Table Iにまとめて 示す。育成結晶の結晶構造の同定は粉末X線回 折法により行ない, また, 組成解析, $\mathrm{Nd}$ 偏析 係数の決定のための化学分析はICP発光分光法
Table I $\mathrm{YVO}_{4}$ growth conditions.

\begin{tabular}{ll}
\hline \hline Heating System & $\mathrm{RF}$ heating $(200 \mathrm{kHz})$ \\
Crucible & $\mathrm{Ir}, 50 \mathrm{~mm} \phi \times 50 \mathrm{mmH}$ \\
Raw Material & $\mathrm{Y}_{2} \mathrm{O}_{3}$ purity $99.9999 \%$ \\
& $\mathrm{~V}_{2} \mathrm{O}_{5} \quad 99.99 \% \mathrm{up}$ \\
& $\mathrm{Nd}_{2} \mathrm{O}_{3} \quad 99.999 \%$ \\
Nd concentration & $0,2.0$ at\% (in starting \\
& material) \\
Seed & Ir wire \\
& a-axis \\
& $\mathrm{c}$-axis \\
Pulling rate & $1 \sim 3 \mathrm{~mm} / \mathrm{h}$ \\
Rotating rate & $6 \mathrm{rpm}$ \\
Atomsphere & $\mathrm{N}_{2}$ base $\mathrm{O}_{2} 0.1 \sim 1 \%$ \\
\hline
\end{tabular}

により行なった。

育成結晶の，熱処理による光吸収特性への影 響を調べるため，酸素雾同気中での熱処理実験 を行なった。熱処理は $30 \mathrm{~mm} \phi$ の開管中で行な い, 酸素流量毎分 $0.5 \ell$, 処理温度は $800^{\circ} \mathrm{C}$,

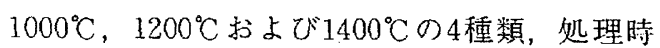
間は全て10時間, 系温扔よび降温速度は毎時 $200^{\circ} \mathrm{C}$ とした。

\section{2 光吸収および屈折率測定}

育成結晶および熱処理結晶の吸収特性を島津 製作所製の分光光度計UV-365を用いて測定し た。まず，ホストの吸収を見るため，undoped $\mathrm{YVO}_{4}$ 育成結晶加ら $4 \mathrm{~mm} \times 4 \mathrm{~mm} \times 25 \mathrm{~mm}$ の試料 ( c 軸)を切りだし光学研磨を施し, 吸収スペク トルを测定した。次に，前項に述べた条件に従 い, 酸素中での熱処理を順次行ない，その都度 吸収測定を行なっだ。次に, 主としてNdによ る吸収の様子を調べるため，Nd 1 at％ doped 結晶を厚さ $2.0 \mathrm{~mm}$ の板状に切りだし ( $\mathrm{c}$ 板) 研 䄷した。なお，比較のため同寸法，同 $\mathrm{Nd}$ 濃度 の Nd: Y AG 結晶試料も用意した。吸収測定の 波長範囲は200〜1100 nmとした。

$\mathrm{YVO}_{4}$ の屈折率測定は精度の高い最小偏角法 により行なった。試料には, undoped $\mathrm{YVO}_{4} を$ 用いた。 $\mathrm{YVO}_{4}$ はジルコンーゼノタイム型の結 晶で正方晶形（D 19 14/amd）に属するので光 
学的には一軸性を示す。従って, 主屈折率つま $\eta, a$ 軸方位と $\mathrm{c}$ 軸方位の常光, 異常光の屈折 率を测定すれば，屈折率の方向性に関する情報 として充分である。屈折率測定用の単結晶につ いては，特にHe-Neレーザー光による透過試験 (インクルージョン，スキャッター), 偏光観察 （光学奀み）を厳密に行ない測定試料として充 分な均一性が確保されていることを確認し，屈 折率の正確な值が得られるよう配慮した。屈折 率測定用のプリズムは $\mathrm{a}$ 軸用と $\mathrm{c}$ 軸用の 2 個作 成した。プリズムは，屈折率のお拉よその值を 1.9 2.0と見積って頂角を 30 度とし，受光面は $1 \mathrm{~cm} \times 1 \mathrm{~cm}$ とした。測定は島津製作所製 $\mathrm{GM}-1$ 精密分光計を用いて行ない，検出器にはNEC製 暗視管6929および昭和光機製赤外望遠鏡を用い た。測定光の分光にはリッー応用光学の ML-10Nモノクロメー夕を用いた。

\section{3.結果および考察}

\section{1 単結晶育成}

$\mathrm{Nd}$ 原料中に $2.0 \mathrm{at} \%$ 添加して育成した $\mathrm{Nd}$ ： $\mathrm{YVO}_{4}$ 单結晶の外形をFig. 1 に示す。結晶寸法 は全長 $50 \mathrm{~mm}$, 平均径約 $20 \mathrm{~mm}$ で, 結晶中に割 れや光散乱体は全く見られなかった。 Table II に重量71.6g（訨込み原料に対する結晶化率 $23 \%$ )のNd: $\mathrm{YVO}_{4}$ 育成結晶の組成分析の結果を $R ： V k$ 換算して示す。ここでRは希土のモル数 つまりYとNdとのモル数の和を示し， $R: V=1$ : 1であれば化学式通りということになる。結 果では全体的にバナジウムが僅かに少ないよう に見えるが，分析精度士 $3 \%$ を考慮すると，結 晶組成比はほぼ1：1と見做せる。次に結晶先端 と末端の組成を見ると誤差範网で一致している ので，組成ずれはほとんどないものと考えられ る。このことは, 結晶上部下部の光学特性に変 化がないことからも確認されている。残留物中 のバナジウムが幾分減少しているが，これは育 成中にわずかに，原料融液表面から分解飛散し たためと思われる。次にNd：YVO 4 結晶育成に おけるNdの実效偏析係数の計算結果について 述べる。Table III は結晶化乷 $21 \%$ O $\mathrm{Nd}: \mathrm{YVO}_{4}$

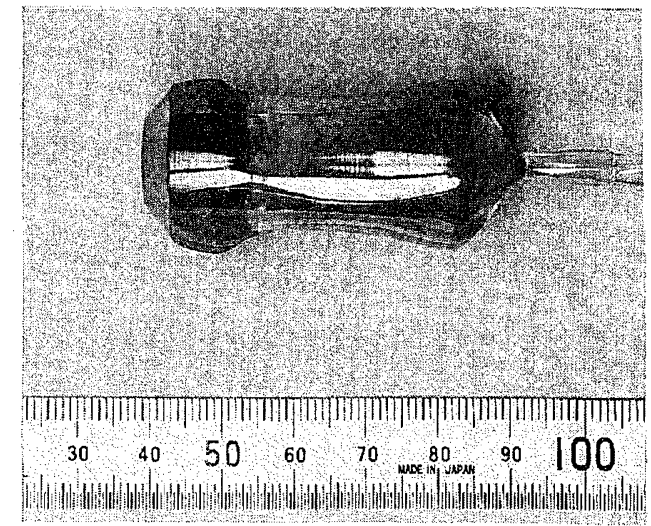

Fig.1 Nd: $\mathrm{YVO}_{4}$ single crystal.

Table II Mole ratio $\mathrm{R}: \mathrm{V}$ of $\mathrm{Nd}: \mathrm{YVO}_{4}$ crystal.

\begin{tabular}{|l|cc|}
\hline \multirow{2}{*}{ Sample } & \multicolumn{2}{|c|}{ Mole ratio } \\
& $R(\mathrm{Y}+\mathrm{Nd}): V$ \\
\hline Starting material & 1 & 0.97 \\
Crystal top & 1 & 0.98 \\
Crystal tail & 1 & 0.97 \\
Residual melt & 1 & 0.95 \\
\hline
\end{tabular}

* Crystal weight : $71.6 \mathrm{~g}$ (Solidification ratio $23 \%$ )

Table III Nd Concentration in crystal (ICP analysis).

\begin{tabular}{|lc|}
\hline \multicolumn{1}{|c|}{ sample } & Nd Concentration (at \%) \\
\hline Starting material & $C_{1}=2.23$ \\
Crystal top & $C_{2}=1.26$ \\
Crystal tail & $C_{3}=1.36$ \\
\hline
\end{tabular}

の, 原料中, 結晶先端, 結晶末端の $\mathrm{Nd}$ 濃度を ICP 発光分光分析の結果をもとに計算した数值 である。実効偏析係数 $\left(K_{\text {eff }}\right)$ は次式から 0.57 であることが判った。

$$
K_{\text {eff }}=C_{1} / C_{2}=0.57 .
$$

次に, 結晶末端の濃度 $C_{x}$ は偏析の一般式に従 えば, 結晶化率Xと初期結晶中の $\mathrm{Nd}$ 濃度 $C_{\mathrm{i}}$ を用 い次のように表される。

$$
\mathrm{C}_{\mathrm{x}}=C_{\mathrm{i}}(1-X)^{\mathrm{keff}-1}
$$

実効偏析係数の計算值 0.57 と結晶化率 0.21 を用 
いて (2) 式より $C_{3}$ を計算すると $C_{3}=1.39$ at \%と なり, Table III の実測值と約 $2 \%$ の誤差で一致 した。このことは， $\mathrm{Nd}: \mathrm{YVO}_{4}$ 結晶育成におけ る実効偏析係数，0.57が正しい事と， $\mathrm{YVO}_{4}$ 結 晶の引き上げ育成において，偏析の一般式が成 立することを示している。実効偏析係数 0.57 と いう数值は Nd：YAGの0.18に較べ遥かに大き く，結晶へのNd添加が容易な事を示している。 実際に育成実験においても，Ndを1\%程度添 加しても無添加の場合と結晶性に大きな変化は 見られなかった。また， 2 at％以上の添加も容 易であった。現在良質結晶が再現性よく得られ ているが，組成ずれが少なく，光学的性質の優 れた良質結晶を得るための条件を要約すると

（1）高純度原料を使用する，（2）原料充填時 および結晶育成時の温度管理を厳密に行う，(3) 原料融液を過热しない，などであるが，青成炉 の構造や，育成パラメータ一も勿諭重要な要素 であり，最適化を計る必要がある。

\section{2 育成結晶の光吸収特性}

Fig. 2 にundoped育成結晶掞よびそれを酸素 中で熱処理した場合の吸収スペクトルを示す。 この結果では $800^{\circ} \mathrm{C}, 10$ 時間の処理では as-grown結晶と変わりない結果になっている

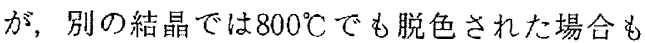
あった。おそらく，結晶育成時の雲围気ガス中 の僅かな酸素分圧の相違によって酸素搪散の活

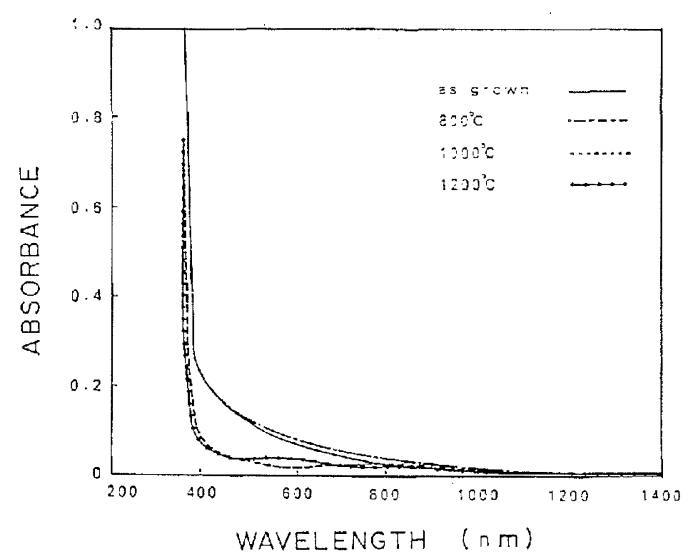

Fig.2 Absorption spectra of $\mathrm{YVO}_{4}$.

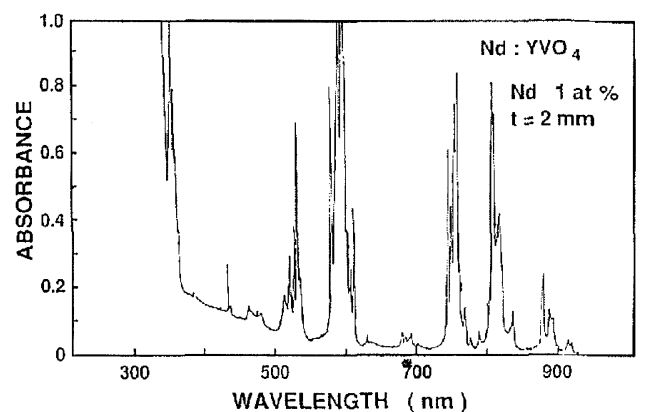

Fig.3 Absorption spectrum of $\mathrm{Nd}: \mathrm{YVO}_{4}$.

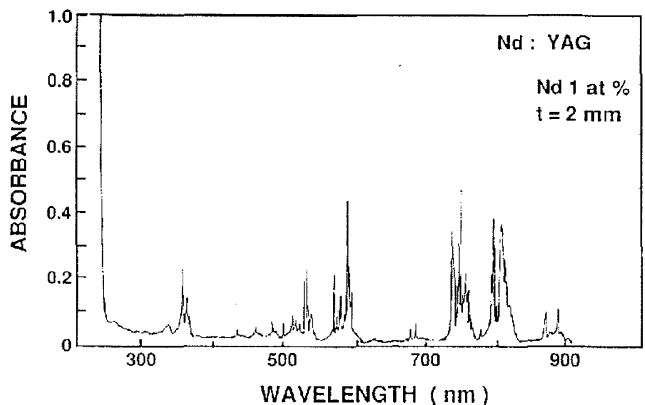

Fig.4 Absorption spectrum of Nd : YAG.

性化エネルギーが変わってくるためと考えられ る。LD励起の場合さほど問題とならないが, 完全に脱色したい場合は $1200^{\circ} \mathrm{C} ， 10$ 時間の酸素 中処理が適当と思われる。なお $1400^{\circ} \mathrm{C}$ 以上では 結晶内部に局所的分解によると思わ机る光散乱 体を生じた。Fig. 3 にNd：YVO 4 C板の吸収スペ クトルを示す。Nd濃度は1.0at％，板厚 $2.0 \mathrm{~mm}$ である。Fig. 4 はNd: YAG結晶でNd濃度は同 じく $1.0 \mathrm{at} \%$ ，板厚も $2.0 \mathrm{~mm}$ で同一である。 $\mathrm{Nd}^{3+}$ による吸収はNd：YVO の約 2 倍以上強い。 $\mathrm{Nd}$ 濃度 1 at\%のYVOA では $\mathrm{Nd}$ 原子の個数は約 $1.2 \times 10^{20} / \mathrm{cm}^{3}$, 一方, $\mathrm{Nd}$ : YAG では約 $1.5 \times 10^{20} / \mathrm{cm}^{3}$ と，むしろ $\mathrm{Nd}$ ： $\mathrm{YVO}_{4}$ の才が単位体積当たりのイオン数が少な いにもかかわらず大きな吸収を示して扔り，小 型レーザーに適した素材であることを示してい る。特にLD励起マイクロチップレーザーなど, 超小型レーザー用として期待される。 
$3.3 \mathrm{YVO}_{4}$ の屈折率

屈折率測定には, $\mathrm{YVO}_{4}$ の今後の様々な応用 の際の基礎資料とするためundoped結晶を用い た。a軸試料( $\mathrm{a}$ 軸方向の屈折率を求めるための プリズム)での 2 つ屈折率測定值を $n_{1 \mathrm{a}}, n_{2 \mathrm{a}}$, $\mathrm{c}$ 軸試料での測定值を $n_{1 \mathrm{c}}, n_{2 \mathrm{c}}$ とすると, 測定結 果は $n_{1 \mathrm{a}}=n_{1 \mathrm{c}}=n_{2 \mathrm{c}}$ で $n_{1 \mathrm{a}}<\mathrm{n}_{2 \mathrm{a}}$ であった。このこ とか⿰ $\mathrm{YVO}_{4}$ は光学的一軸性正号結晶で光軸が $\mathrm{c}$ 軸であることがわかった。測定結果を主屈折 率 $\omega$ (常光) $\varepsilon$ (異常光)にまとめてTable IVおよ びFig. 5 に示す。測定誤差は0.0005以内である。 Fig. 6 は波長1000 nmでの屈折率曲面の $\mathrm{a}-\mathrm{c}$ 軸 断面を示したもので常光, 異常光の屈折率差が かなり大きいことが判る。

今回の測定はundoped結唱を用いたがNdを 1 at％程度添加した場合でも然程值は変らないも のと思われる。このことは例えば， $\mathrm{YAlO}_{3}$ の場 命から予測できる ${ }^{10)}$ 。 $\mathrm{YAlO}_{3}$ は二軸性結晶で, 波長 $1000 \mathrm{~nm}$ での主屈折率は $n_{\alpha}=1.9111, n_{\beta}$ $=1.9250, n_{\gamma}=1.9337$ ある。この結晶にNd が1.1at\%添加された場合の主屈折率は $n_{\alpha}=$ $1.9125, n_{\beta}=1.9262, n_{\gamma}=1.9351$ で undoped とNd $1 \%$ 程度添加された場合の屈折率差はほ ぼ0.001程度である。こうした例から， $\mathrm{YVO}_{4} に$

Table IV Principal Refractive Indices of $\mathrm{YVO}_{4}$.

\begin{tabular}{|c|cc|}
\hline Wavelength & \multicolumn{2}{|c|}{ Refractive Indices } \\
\cline { 2 - 3 }$(\mathrm{nm})$ & $\omega$ (Ordinary) & $\varepsilon$ (Extraordinary) \\
\hline 500 & 2.0297 & 2.2679 \\
550 & 2.0119 & 2.2428 \\
600 & 1.9995 & 2.2247 \\
650 & 1.9899 & 2.2111 \\
700 & 1.9825 & 2.2007 \\
750 & 1.9767 & 2.1924 \\
800 & 1.9721 & 2.1858 \\
850 & 1.9682 & 2.1804 \\
900 & 1.9650 & 2.1759 \\
950 & 1.9621 & 2.1720 \\
1000 & 1.9598 & 2.1687 \\
1050 & 1.9577 & 2.1657 \\
1100 & 1.9558 & 2.1631 \\
\hline
\end{tabular}

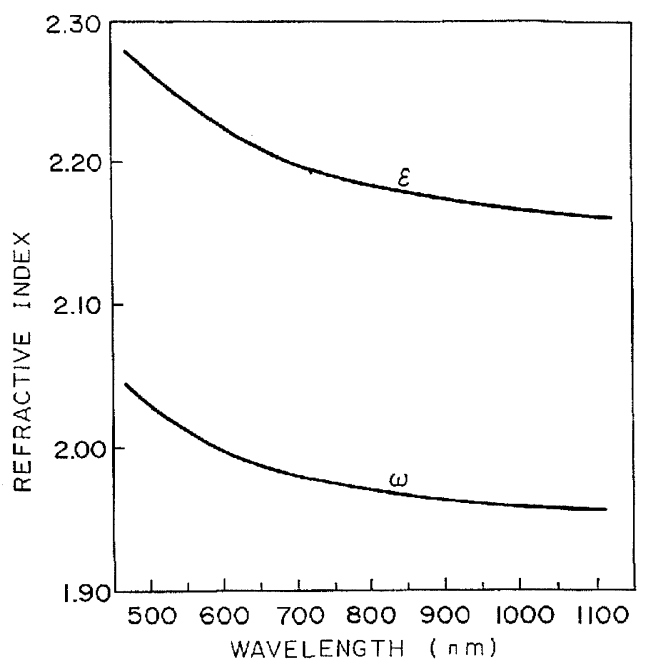

Fig. 5 Refractive indices of $\mathrm{YVO}_{4}$.

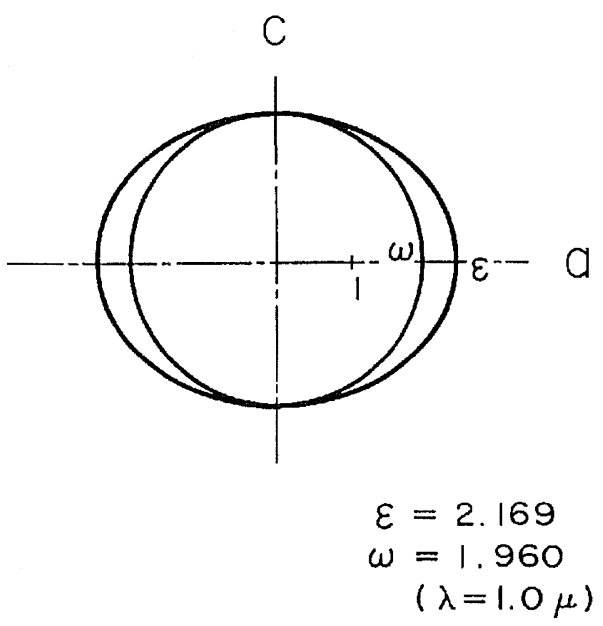

Fig. 6 Curved surface of $\mathrm{YVO}_{4}$ refractive index. (a-c cross section)

おいても $\mathrm{Nd} 1$ at \% 程度の添加では小数点以下 3 桁目が僅かに增加する程度と推定される。

\section{4.まとめ}

高周波加熱引き上げ法により， $\mathrm{YVO}_{4}$ および $\mathrm{Nd}$ : $\mathrm{YVO}_{4}$ 単結晶を育成した $\mathrm{YVO}_{4}$ は分解性の バナジウム酸化物を原料とするため良質結晶の 育成が困難とされてきたが原料および育成中の 
温度管理を工夫することにより，常圧下で，組 成ずれの少ない結晶を得た。さらに，Ndの添 加害験加ら Ndの実効偏析係数が 0.57 であこ とが明らかになった。育成結晶には短波長域に 吸収がみられたが， $1200^{\circ} \mathrm{C} ， 10$ 時間の酸素中熱 処理よって改善された。 $\mathrm{Nd}: \mathrm{YVO}_{4}$ の)活性元素 $\mathrm{Nd}$ にる光吸収の強さは同一濃度のNd: Y AG の 2 倍以上あり，LD励起超小型レーザー用と して優れた材料であることが分かった.YVO レーザー用，その他光学用として用いる場合， 基礎物性值として屈折率の正確な値が必要とな るため，a軸方向㧍よびc軸方向の屈折率測定用 プリズムを製作し，主屈折率の測定を行なった。 測定值の一例として， $\mathrm{Nd} ： \mathrm{YVO}_{4}$ レーザーの主 な発振波長である, 波長 $1064 \mathrm{~nm}$ では $\omega=$ 1.9573 (常光),$\varepsilon=2.1652$ (異常光)であった。

終わりに，本稿をまとめるにあたり御指導戴 いた大阪大学助教授山中正宣氏に深く感謝致し ます。

\section{参 考 文 献}

1）永本，中塚，内藤，山中，吉田，佐々木，金辺， 中井, 斎藤, 桑野：レーザー研究 18, No.8 (1990).

2）山岸，山口，杉元，横谷，佐々木，中井，山 下：レーザー学会第 154 回研究会報告 RTM-89-16 (1989) 57.

3) R.A.Fields, M.Birnbaum and C.L.Fincher : Appl. Phys. Lett. 51 (1987) 1885.

4) R.A.Fields, M.Birnbaum and C.L.Fincher: CLEO Digest PD3-1 (1988) 460.

5) V.I.Popov, Kh.S.Bagdasarov, I.N.Guseva and M.V.Mokhosoev: Kristallografia 13 (1968) 1109.

6) Yu.P.Udalov: Izv. Akad. Nauk, SSSR 18 (1982) 1349.

7) B.M.Wanklyn: J. Cryst. Growth 54 (1981) 610.

8) J.Loriers and M.Vichr: J. Cryst. Growth 13-14 (1972) 593.

9) H.M.Dess and S.R.Bolin: Trans. Metall. Soc. AIME 293 (1967) 359.

10) K.W.Martin and L.G.DeShazer: Appl. Opt. 12 (1973) 941. 